\title{
Assessment of Silicon Status in Calcareous Soils of Banger Elsokkar Region, Egypt \\ Hoda A.Argeaa ${ }^{1}$, Maher G. Nasseem ${ }^{2}$, Hoda A.Mahmoud ${ }^{2}$ and Magda A.Hussein ${ }^{2}$
}

\begin{abstract}
There are a few studies present silicon status in Egyptian soils. Hence this study was initiated with the objective of understanding Si status in calcareous soils of Banger Elsokkar region, Egypt. Twenty six soil samples were collected from 3 villages of the region to cover 810.37 hectare. Total $\mathrm{Si}$ and fractions were determined. The results revealed that total $\mathrm{Si}$ ranged from311.2 to $\mathbf{5 7 6 0 . 0}$ $\mathrm{mg} \mathrm{Si} \mathrm{kg}^{-1}$ soil. The highest concentration was found in the coarse textured soils. Also, sand, silt and clay contents are more effective in contribution to total $\mathrm{Si}$ content. The classification technique of manual, which was introduced by Arc GIS software, decided to classify the area into 6 zones and the dominant total Si class was 3001 to $4000 \mathrm{mg}$ $\mathrm{Si} \mathrm{kg}^{-1}$ soil covered about $43 \%$ of the area followed by the class 2001 to $3000 \mathrm{mg} \mathrm{Si} \mathrm{kg}^{-1}$ soil and covered $30 \%$ of the area. The results of sequential extraction indicated that most of the Si was mobile which represents $35.69 \%$ of the total. Also, the classification technique of manual, which was introduced by Arc GIS software, decided to classify the area into 6 zones and the dominant mobile Si class was 1001 to $1500 \mathrm{mg} \mathrm{kg}^{-1}$ soil covered about $43.7 \%$ of the total area followed by the class 800 to $1000 \mathrm{mg} \mathrm{kg}^{-1}$ soil and covered $31.7 \%$ of the total area. The amorphous fraction was the lower level and represented $5.38 \%$ of the total Si. The results also, indicated that about $11.36 \%$ of total $\mathrm{Si}$ is bound in primary and secondary silicates.
\end{abstract}

Keywords: Amorphous, Fraction, Mobile, Total Si, Sequential extraction.

\section{INTRODUCTION}

Silicon(Si) has been demonstrated to be beneficial for the growth of plants, to alleviate both biotic and abiotic stresses (Epstein, 1994). In other reports, Si was implicated to ameliorate the adverse effects of aluminium toxicity (Hammond et al., 1995), manganese toxicity (Iwasaki et al., 2002), and salinity (Liang et al., 1996).

Generally, silicon has more benefits such as the mobilization of soil phosphorus (Marschner, 1996), reduction of water loss by cuticular transpiration, and increased resistance against lodging and pests. It is clear therefore, that $\mathrm{Si}$ deserve more attention in the future in crops other than rice and sugarcane (Marschner, 1996). Numerous laboratory, greenhouse and field experiments showed sustainable benefits of $\mathrm{Si}$ fertilization for rice, barley, wheat, maize, sugarcane, cucumber, tomato, citrus and other crops (Matichenkov and Calvert, 2002).

Silicon is the second most abundant element in the earth's crust after oxygen. More than $26.3 \%$ of the earth's crust's mass is silicon (Holleman and Wiberg, 2007). Nevertheless, the silicon turnover in soils - an important compartment within the global silicon cycle - has received little attention so far. The lack of knowledge to the basic magnitudes of the release from soil is partly due to the fact, that no technique for quantitative extraction is available for the Si Pools in soils in the sense of a chemical fractionating extraction method (Sauer et al., 2006). A large variety of silicon fractions may occur in soils. Anna et al. (2010) stated that soil particle can adsorb dissolved silicic acid from the soil solution. In addition silica can be included in sesquioxides or bound to organic matter, amorphous silica exists in the form of biogenic and minerogenic opal, dissolved silicic acid form is retained in the soil solution and many primary and secondary crystalline silicates are generally found in soils.

The present study was carried out with the objectives of auditing the current $\mathrm{Si}$ status in agriculturally soils of the Banger Elsokkar region of Egypt and suggest way forward with Si fertilization in crop production. Determination of total and fractions of $\mathrm{Si}$ in the soil and mapping should help to solve practical problems involving the need for Si fertilizers.

\section{MATERIALS AND METHODS}

\section{Study area location}

Banger El-Sokkar region is located $55 \mathrm{~km}$ south west of Alexandria city. It is bounded by Alex-Cairo desert road from the East, El-Nasr Canal from the South and the West, and Bahig canal from the North. El Banger region runs west and North West covering an approximately 47395.83 hectares. The study area extends to cover villages 1,2 and 3 with total area of 810.37 hectares. It lies approximately between latitudes 3047 and $3050 \mathrm{~N}$ and longitudes 2944 and $2947 \mathrm{E}$. (Map1).

\section{Soil sampling and analysis}

Twenty six augers were dug (Map 2) and the samples represent the surface horizon $(0-30 \mathrm{~cm})$ were

\footnotetext{
Omar Elmokhtar university, Elbeda,Libya.

${ }^{2}$ Soil and agriculture chemistry department, faculty of agriculture,

Saba Basha, Alexandria, Egypt.

Received February 3, 2016, Accepted March 6, 2016
} 
collected. The soil samples were air dried and greatly crushed with a wooden pestle, sieved through $<2 \mathrm{~mm}$ sieves and then subjected to laboratory analysis. The soil chemical $(\mathrm{pH}$, Electrical conductivity $(\mathrm{EC})$, calcium carbonate $\left(\mathrm{CaCO}_{3}\right)$, organic matter $(\mathrm{OM})$, soluble ions; calcium $\left(\mathrm{Ca}^{+2}\right)$, magnesium $\left(\mathrm{Mg}^{+2}\right)$, sodium $\left(\mathrm{Na}^{+}\right)$, potassium $\left(\mathrm{K}^{+}\right)$, bicarbonate $\left(\mathrm{HCO}_{3}{ }^{-2}\right)$, Sulphate $\left(\mathrm{SO}_{4}{ }^{-2}\right)$, and mechanical analysis were carried out according to the methods described by page et al. (1982).

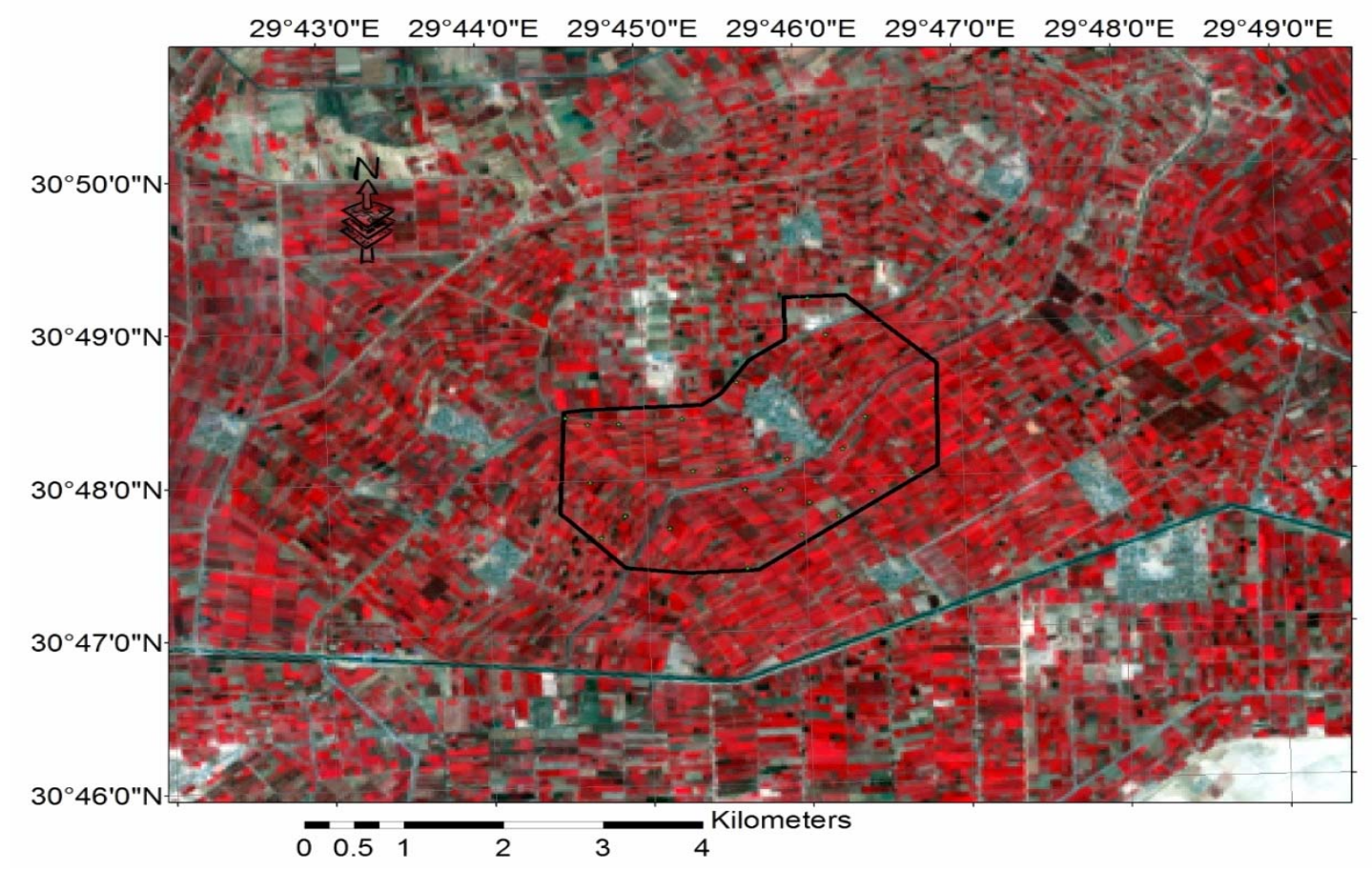

Map 1. The general location of the study area

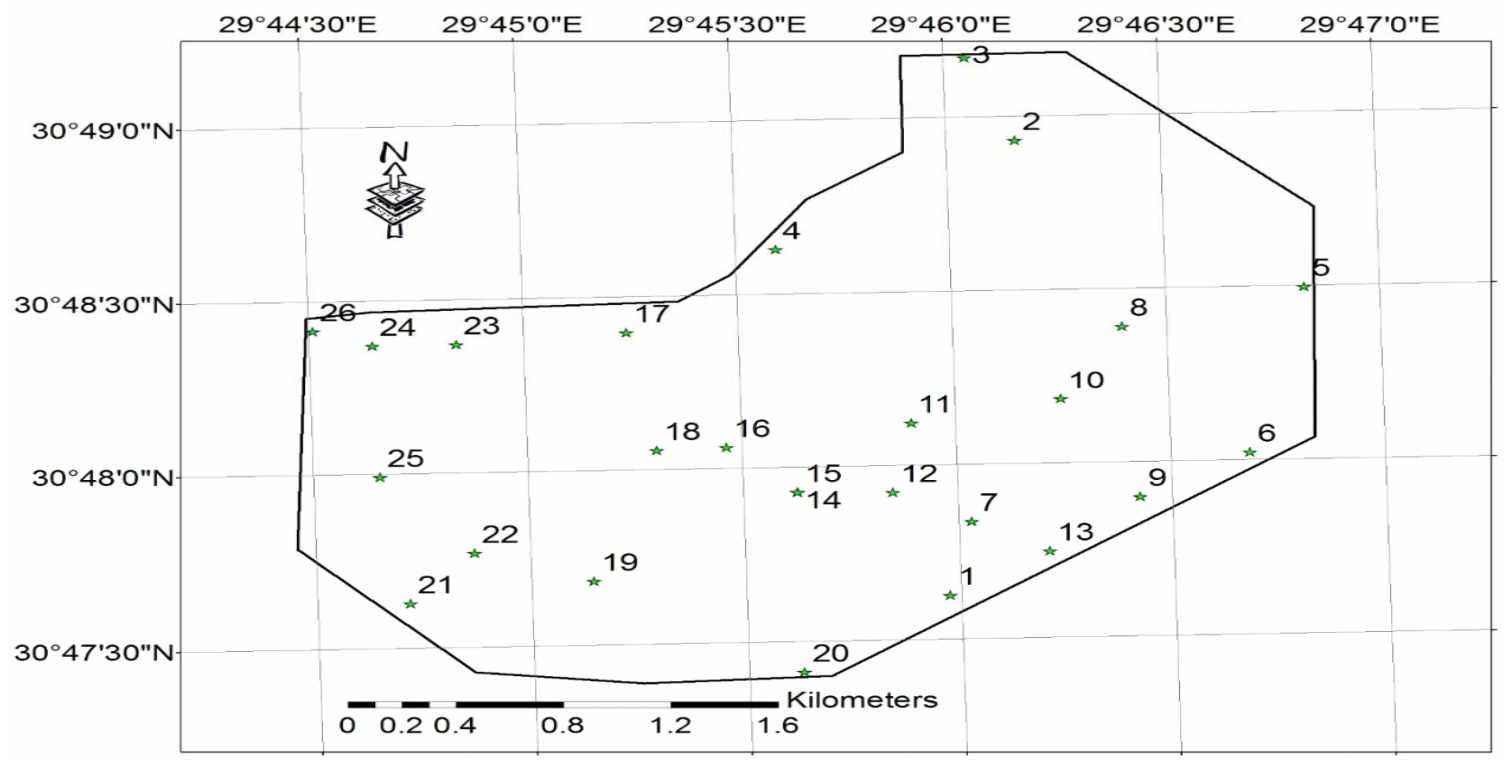

Map 2. The soil sample locations of the study area 


\section{Total Silicon Determination}

The soil samples were digested for total $\mathrm{Si}$ following the procedure of Buckley and Cranston (1971). Triplicate subsamples of one gram oven dry soil was transferred to a $120 \mathrm{ml}$ Teflon pressure digestion vessel followed by adding $4 \mathrm{ml}$ of $\mathrm{HF}$ and were allowed to react overnight in order to ensure dissolution of silicate matrix. The vessels were placed on a hot plate until the white paste was obtained. Thereafter, the vessels were removed from the hot plate and allowed to cool at room temperature. The white paste in the vessel was treated with $10 \mathrm{ml}$ of aqua regia $\left(1: 3 \mathrm{HNO}_{3}: \mathrm{HCl}\right)$ and was placed on the hot plate for 30-min to ensure dryness. After dryness, yellowish brown residue was dissolved in $20 \mathrm{ml}$ of $2 \mathrm{~N} \mathrm{HCl}$. It was placed on a hot plate for an additional 5-10 min to ensure re-digestion but avoid complete dryness. Boric acid ( $1 \mathrm{~g}$ ) was added after digestion in order to prevent the volatilization losses of the $\mathrm{SiF}_{4}$ gas. After cooling, yellowish brown dry residue was diluted with $30 \mathrm{ml}$ of distilled water and was mixed thoroughly by continuous manual shaking for $5 \mathrm{~min}$ and was filtered. The filtered aliquots of each residue were analyzed for Si.

\section{Estimating silicon forms}

Sequential extraction of the soil samples was done according to the method described by Anna et al. (2010). Firstly, the most mobile phase is separated by extraction with $0.01 \mathrm{M} \mathrm{CaCl}_{2}$, followed by extraction of the adsorbed $\mathrm{Si}$ with $0.01 \mathrm{M}$ acetic acid. Thereafter; the fraction of silicon occluded in sesquioxides is isolated by treatment with oxalate solution in the light. Subsequently, the samples were treated with $\mathrm{H}_{2} \mathrm{O}_{2}$ to release silicon bound in organic matter. Afterwards the samples were extracted with $0.2 \mathrm{M}$ sodium hydroxide at room temperature in three time steps $(5 \mathrm{~h}, 24 \mathrm{~h}$ and $48 \mathrm{~h}$ ), to calculate the amounts of $\mathrm{Si}$ from amorphous silica using the modified method of De Master (1981). After analyzing the previous fractions, the balance of silicon in the samples could be established as follows:

$\mathrm{Sit}=\mathrm{Simo}_{\mathrm{mo}}+\mathrm{Si}_{\text {ad }}+\mathrm{Si}_{\text {occ }}+\mathrm{Si}_{\text {org }}+\mathrm{Si}_{\text {am }}+\mathrm{Simin}$.

Where: $\mathrm{Sit}$ is total silicon in the sample, $\mathrm{Sim}_{\mathrm{m} o}$ is silicon from the mobile phase, $\mathrm{Si}_{\mathrm{a}}$ is silicon from adsorbed silica, $\mathrm{Si}_{\text {occ }}$ is silicon occluded in sesquioxides, $\mathrm{Si}_{\text {org }}$ is silicon bound to organic substances, $\mathrm{Si}_{\mathrm{am}}$ is silicon from amorphous silica and $\mathrm{Simin}_{\mathrm{m}}$ is silicon from primary and secondary silicates which calculated by subtracting sum of the other fractions from total Si content.

The silicon in each soil solutions was determined using atomic absorption spectrophotometer (Analytika
Jena, Germany). Soil quality data can be presented in the form of GIS-based geochemical maps to provide knowledge for the spatial characteristics of the chemical data. Soil quality maps represent a method describing the chemical data either individual mapping of total or the mobile amounts of Si. The mapping should help to solve practical problems involving the need for $\mathrm{Si}$ fertilizers. GIS software package (ESRI Arc GIS) is used to map the analyzed data for spatial soil quality evaluation.

\section{RESULTS AND DISCUSSIONS}

The description of the soil samples used in this investigation is shown in Table(1). The soil samples show different three texture classes (Loamy Sand, Sandy Loam and Silt Loam)and chemical properties. In general, the soils are typic calciorthids.

\section{Total silicon in soil}

The obtained results show that total silicon content in the tested calcareous soils varied between 311.2 and $5760.0 \mathrm{mg} \mathrm{kg}^{-1}$ soil with an average of $3050.2 \mathrm{mg} \mathrm{kg}^{-1}$ soil in comparison with the normal soil range $(<1$ to 450 $\mathrm{g} \mathrm{kg}^{-1}$ soil) (Sommer et al., 2006) or the ranges from 200 to $300 \mathrm{~g} \mathrm{Si} \mathrm{kg}^{-1}$ in clay soils and 450 to $480 \mathrm{~g} \mathrm{Si} \mathrm{kg}^{-}$ 1 in sandy soils (Kovda, 1973; Matichenkov and Calvert, 2002) which suggests little Si contents in these calcareous soils. The comparatively lower values for $\mathrm{Si}$ in these soils can be justified due to; first, severe and frequent soil erosion and sediment transportation in the study area. Secondly, usually plants absorb Si more than other elements (Savant et al., 1997); hence, much Si should be replaced to ensure sustainable yields. Thirdly, the nature of parent materials in the study area could be the cause for the lowered Si levels in these soils.

The total $\mathrm{Si}$ in soil of the studied area can be grouped according to the texture as shown in Figure (1). For all soils, however, the total content of Si increased as the soil becomes coarse in texture. Virtually, the main portions of soil Si-rich compounds are represented by quartz or crystalline silicates, which are confirmed in the current studies where the highest total Si content was found in sand dominated soils. Morsy (2008) in his study on the alluvial soils of the Nile valley as well as those of the transitional belts of the desert plateaus in middle Egypt found that, total Si varied greatly from one site to another and ranged between 187.8 to $420.6 \mathrm{~g}$ $\mathrm{kg}^{-1}$ soil. He added that the highest values were obtained from the coarse-textured soils which are located in/or near both eastern and western plateaus, while the lowest values were obtained from the alluvial soils of medium to heavy texture grades.

The simple correlation was used to find a correlation between total silicon and selected soil physical and 
chemical properties as given in Table 1. The test showed that there is no significant correlation between $\mathrm{Si}$ content and $\mathrm{pH}$, soil organic carbon, $\mathrm{CaCO}_{3}, \mathrm{EC}$, clay, silt and sand. Simple correlation measures only direct associations between individual variables. A stepwise regression program was thus conducted to determine the best multiple regression equation relating total $\mathrm{Si}$ content to soil properties. In this program, the maximum $\mathrm{R}^{2}$ improvement technique was used. The best variables regression equation relationship found for total $\mathrm{Si}$ is given in the following equation:

Total $\mathrm{Si}=-391.5-0.10 \mathrm{ECe}+0.94$ (O.M.) + $0.39\left(\mathrm{CaCO}_{3}\right)+3.97$ (sand) +3.39 (silt) +3.66 (clay)

$$
\mathrm{R}^{2}=0.319
$$

Table 1. The range, mean, standard deviation (S.D) and variation coefficient (C.V) for the estimated properties of soils

\begin{tabular}{|c|c|c|c|c|c|}
\hline \multirow{2}{*}{$\begin{array}{c}\text { Soil } \\
\text { properties }\end{array}$} & \multirow{2}{*}{ mean } & \multirow{2}{*}{ S.D } & \multicolumn{2}{|c|}{ Range } & \multirow{2}{*}{ CV\% } \\
\hline & & & Min & Max & \\
\hline $\mathrm{pH}$ & 8.12 & 0.16 & 7.90 & 8.60 & 2.01 \\
\hline $\mathrm{ECe}, \mathrm{dSm}^{-1}$ & 1.67 & 0.96 & 0.64 & 3.63 & 57.36 \\
\hline O.M,\% & 1.61 & 0.41 & 0.74 & 2.39 & 25.39 \\
\hline $\mathrm{CaCO}_{3}, \%$ & 31.99 & 4.53 & 22.60 & 42.75 & 14.15 \\
\hline \multicolumn{6}{|c|}{ Soluble cations, $\mathrm{meqL}^{-1}$} \\
\hline $\mathrm{Ca}^{2+}$ & 7.23 & 4.89 & 2.40 & 22.60 & 120.69 \\
\hline $\mathrm{Mg}^{2+}$ & 3.35 & 2.03 & 1.00 & 7.60 & 60.40 \\
\hline $\mathrm{Na}^{+}$ & 8.20 & 5.01 & 3.00 & 20.30 & 61.09 \\
\hline $\mathrm{K}^{+}$ & 0.26 & 0.11 & 0.10 & 0.50 & 40.58 \\
\hline \multicolumn{6}{|c|}{ Soluble anions, meqL $^{-1}$} \\
\hline $\mathrm{CO}_{3}^{=}$ & 0.17 & 0.72 & 0.00 & 3.60 & 423.73 \\
\hline $\mathrm{HCO}_{3}^{-}$ & 5.73 & 2.20 & 3.20 & 9.40 & 35.20 \\
\hline $\mathrm{Cl}^{-}$ & 8.85 & 5.51 & 4.00 & 22.00 & 62.19 \\
\hline $\mathrm{SO}_{4}=$ & 4.22 & 5.86 & 0.10 & 22.30 & 138.95 \\
\hline \multicolumn{6}{|c|}{ Mechanical properties, $\%$} \\
\hline Sand & 51.08 & 15.25 & 21 & 79 & 29.86 \\
\hline Silt & 40.73 & 15.55 & 16 & 71 & 38.18 \\
\hline Clay & 8.15 & 1.41 & 5 & 12 & 17.24 \\
\hline
\end{tabular}

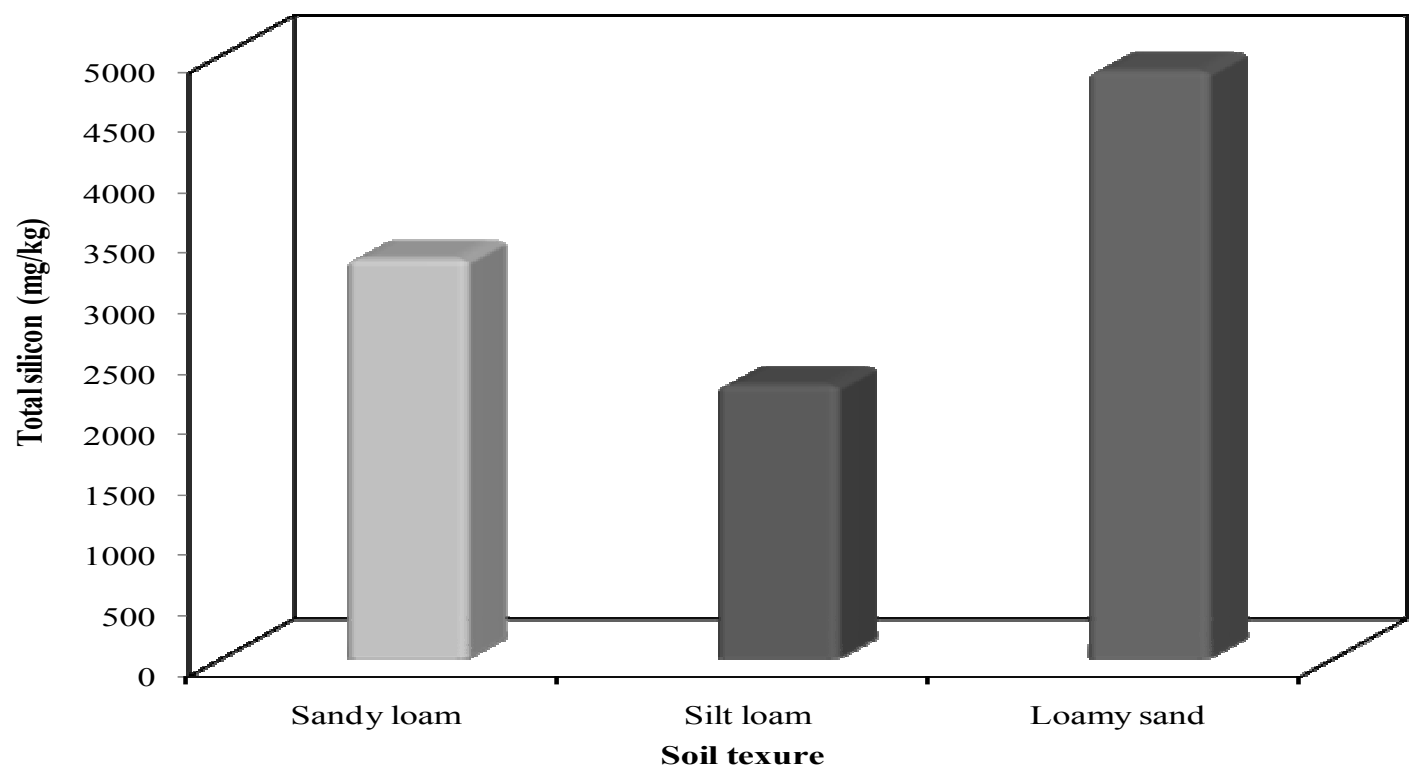

Figure 1. Average total silicon of soils grouped according to textural classes 
The results showed that a multiple regression equation including clay, silt, sand, $\mathrm{EC}$, O.M and $\mathrm{CaCO}_{3}$ contents as independent variables could predict $31.9 \%$ of variance in total Si content values for the tested soils. It is clear from the equation that sand, silt and clay contents are more effective in contribution of total $\mathrm{Si}$ content of the tested soils.

Geostatistical analyses of total silicon were presented according to its semivarioms. The variograms of total $\mathrm{Si}$ was prepared as shown in Figure (2). The classification approach using raster calculator, which was available in the spatial analyst for calculating the total $\mathrm{Si}$ and calculated map was produced. The classification technique of manual, which was introduced by Arc GIS software, was selected to visual variability as groups. This study decided to classify the area into 6 zones which could be manageable and also easy to compare. Map (3) shows the distribution of total $\mathrm{Si}$ in the top soil representing the study area using weighted average. It is clear that, total $\mathrm{Si}$ is variable and ranged from 311.2 to $5760.0 \mathrm{mg} \mathrm{kg}^{-1}$ soil. The dominant total $\mathrm{Si}$ class was 3001 to $4000 \mathrm{mg} \mathrm{kg}^{-1}$ soil covered about $43 \%$ of the area followed by the class 2001 to $3000 \mathrm{mg} \mathrm{kg}^{-1}$ soil and covered $30 \%$ of the area.

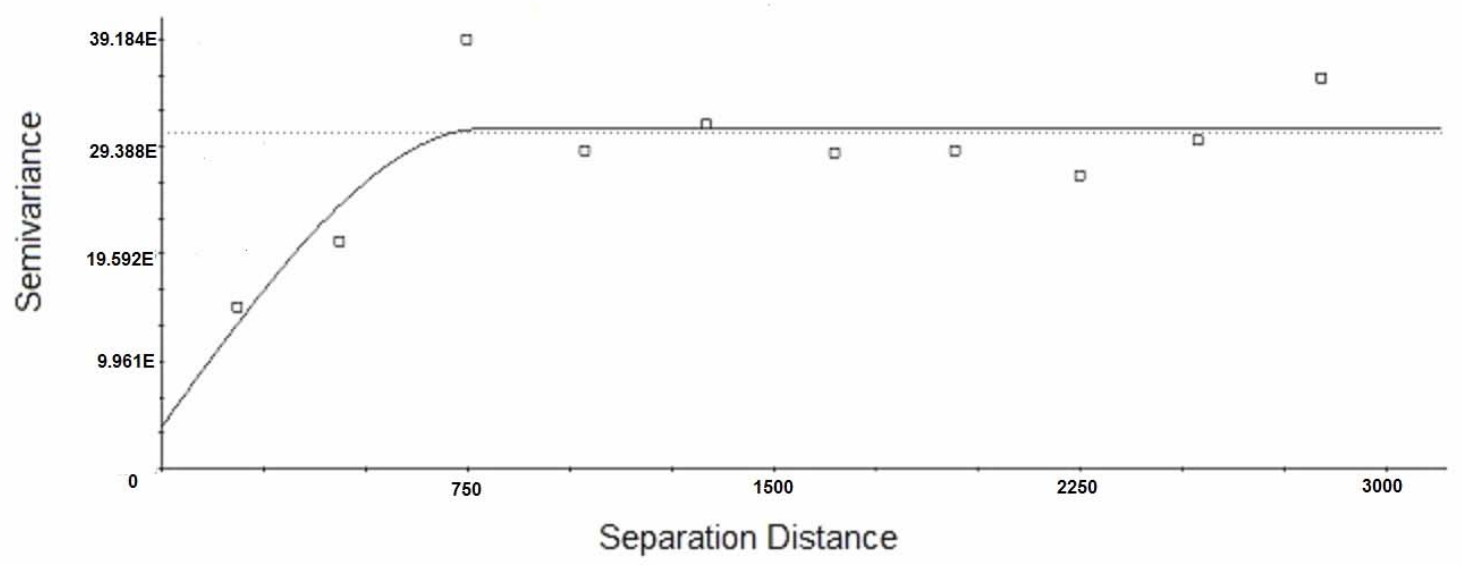

Figure 2. Isotropic semivariogram of total $\mathrm{Si}$, Spherical model $(\mathrm{C} 0=\mathbf{3 8 4 0 0 0 . 0 0 0 0}$; $C 0+C=3103000.0000 ; A 0=793.00 ; R^{2}=0.684 ; R S S=1.347 E$

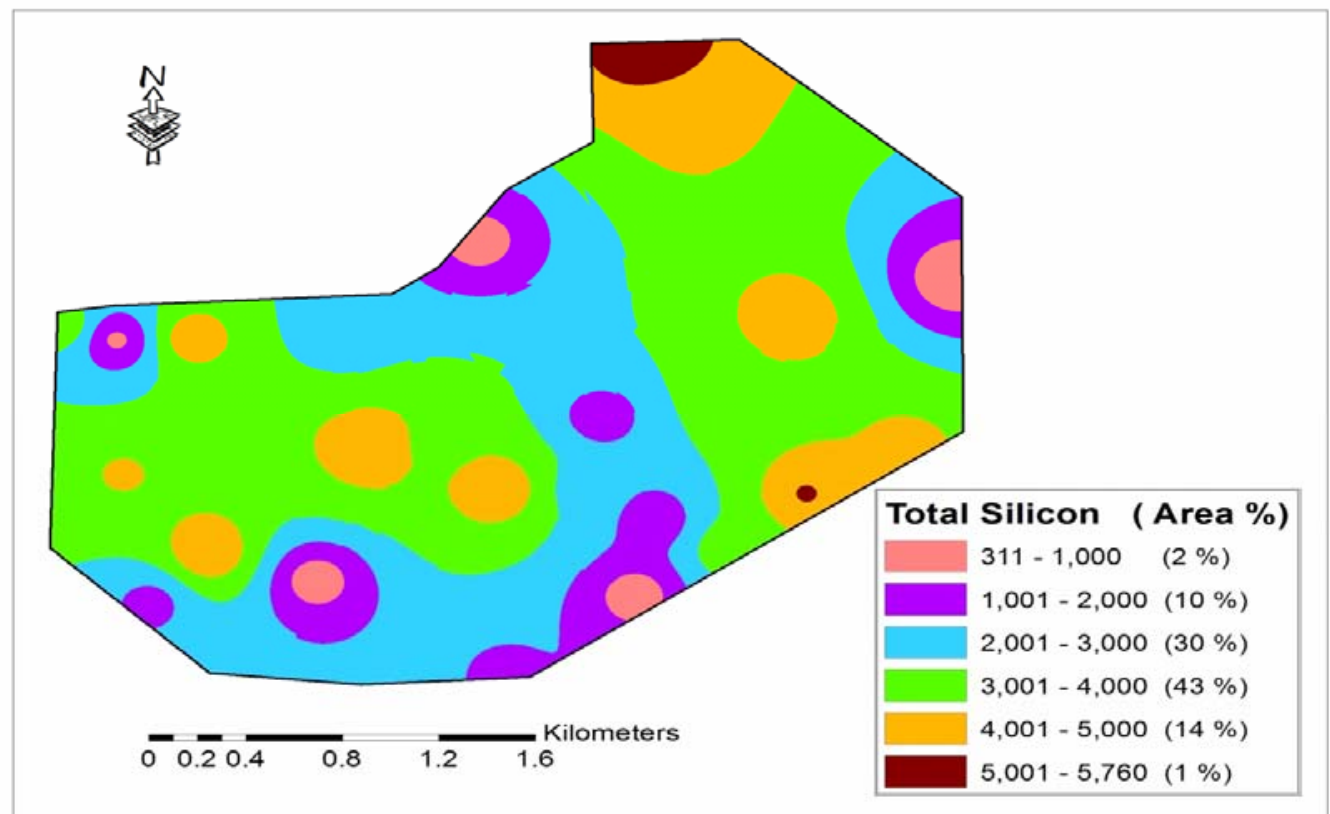

Map 3. Spatial distribution of total silicon $\left(\mathrm{mg} \mathrm{kg}^{-1}\right)$ in the top soil of the area 


\section{Silicon fractions in soil}

The concentrations of $\mathrm{Si}$ fractions or their contributions in the total $\mathrm{Si}$ of all the tested soils were found in Tables( 2) and( 3). The mobile fraction was by far the most important fraction for Si. The values ranged from 105.25 to 2206.25 with an average of $974.11 \mathrm{mg}$ $\mathrm{kg}^{-1}$ soil (Table 2). These values represent 19.87 to 59.88 with an average of $35.69 \%$ of total Si (Table 3 ), respectively. The next important fraction for $\mathrm{Si}$ is the adsorbed fraction having the values ranged from 79.17 to 1102.38 with an average of $659.57 \mathrm{mg} \mathrm{kg}^{-1}$ soil. The percentage range was from 2.44 to 25.28 with average of 16.56 of total Si. The third fraction of $\mathrm{Si}$ is occluded in sesquioxides having values range from 55.88 to 903.06 with an average of $492.15 \mathrm{mg} \mathrm{Kg}^{-1}$ soil. The percentage range values were from 5.56 to 20.83 with an average of 15.03 of total Si. The forth level of Si was associated with organic fraction. The range values were 21.70 to 880.50 with an average range of $357.01 \mathrm{mg}$ $\mathrm{Kg}^{-1}$ soil. These values correspond to percentage values range of 2.74 to 19.27 with an average of 10.20 of total $\mathrm{Si}$. The fifth level of $\mathrm{Si}$ is the lowest which is amorphous fraction having values range of 12.00 to 510.00 with an average of $190.90 \mathrm{mg} \mathrm{Kg}^{-1}$. The percentage range values were from 1.24 to 11.74 with an average of 5.38 of total Si. Higher levels of Si in this fraction have been reported by Morsy (2008), who reported that amorphous $\mathrm{Si}$ in the alluvial soils of the Nile valley as well as those of the transitional belts of the desert plateaus in middle Egypt ranged between 280.45 and $15611.86 \mathrm{mg} \mathrm{kg}^{-1}$ soil. He added also, that the fine textured soils showed the highest values of amorphous silicon. The last fraction of $\mathrm{Si}$ was associated with minerals with range values of 0.73 to 1718.06 and average value of $349.48 \mathrm{mg} \mathrm{kg}^{-1}$ soil (Table 2). The percentage values range was 0.19 to 29.83 with an average of 11.36 of total Si. In the black forest in SW-Germany, the results of sequential extraction indicate that most of the $\mathrm{Si}(98-99 \%)$ is bound in primary and secondary silicates (Anna Danilova et al., 2010).

Since the mobile $\mathrm{Si}$ is the most important fraction for plant growth, geostatistical analyses was presented according to its semivarioms. The variograms of mobile $\mathrm{Si}$ was prepared as shown in Figure(3). The classification approach using raster calculator, which was available in the spatial analyst for calculating the mobile $\mathrm{Si}$ and calculated map was produced. The classification technique of manual, which was introduced by Arc GIS software, was selected to visual variability as groups. Map 4 shows the distribution of mobile $\mathrm{Si}$ representing the study area using weighted average. It is clear that, mobile $\mathrm{Si}$ is variable and ranged from 105.25 to $2206.25 \mathrm{mg} \mathrm{Kg}^{-1}$ soil. The dominant mobile Si class was 1001 to $1500 \mathrm{mg} \mathrm{kg}^{-1}$ soil covered about $43.7 \%$ of the area followed by the class 800 to $1000 \mathrm{mg} \mathrm{kg}^{-1}$ soil and covered $31.7 \%$ of the area.

Table 2. Range, mean, standard deviation (S.D) and variation coefficient (C.V) of silicon fractions ( $\mathrm{mg} \mathrm{kg}^{-1}$ soil)

\begin{tabular}{lccccc}
\hline $\begin{array}{l}\text { Silicon } \\
\text { fraction }\end{array}$ & Mean & S.D & \multicolumn{2}{c}{ Range } & C.V\% \\
\cline { 1 - 3 } F1 & & & Min & Max & \\
\hline F2 & 974.11 & 507.41 & 105.25 & 2206.25 & 52.09 \\
\hline F3 & 659.57 & 398.59 & 79.17 & 1102.38 & 60.43 \\
\hline F4 & 492.15 & 325.55 & 55.88 & 903.06 & 66.15 \\
\hline F5 & 357.01 & 280.00 & 21.70 & 880.50 & 78.42 \\
\hline F6 & 190.90 & 168.12 & 12.00 & 510.00 & 88.07 \\
\hline
\end{tabular}

*F1=Si mo, F2=Si ad, F3= Si occ, F4= Si org, F5= Si am, F6= Si min

Table 3. Range, mean, standard deviation (S.D) and variation coefficient (C.V) of silicon fractions (percent of total)

\begin{tabular}{|c|c|c|c|c|c|}
\hline \multirow{2}{*}{$\begin{array}{l}\text { Silicon } \\
\text { fraction }\end{array}$} & \multirow[t]{2}{*}{ Mean } & \multirow[t]{2}{*}{ S.D } & \multicolumn{2}{|c|}{ Range } & \multirow[t]{2}{*}{ C.V\% } \\
\hline & & & Min & Max & \\
\hline $\mathrm{F} 1$ & 35.69 & 11.29 & 19.87 & 59.88 & 31.63 \\
\hline $\mathrm{F} 2$ & 22.35 & 4.80 & 7.69 & 31.47 & 21.48 \\
\hline F3 & 15.03 & 3.69 & 5.56 & 20.83 & 24.55 \\
\hline F4 & 10.20 & 4.39 & 2.74 & 19.27 & 43.08 \\
\hline F5 & 5.38 & 2.81 & 1.24 & 11.74 & 52.32 \\
\hline F6 & 11.36 & 9.00 & 0.19 & 29.83 & 79.31 \\
\hline
\end{tabular}

*Fractions :F1=Si mo, F2=Si ad, F3= Si occ, F4= Si org, F5= Si am, F6= Si min 


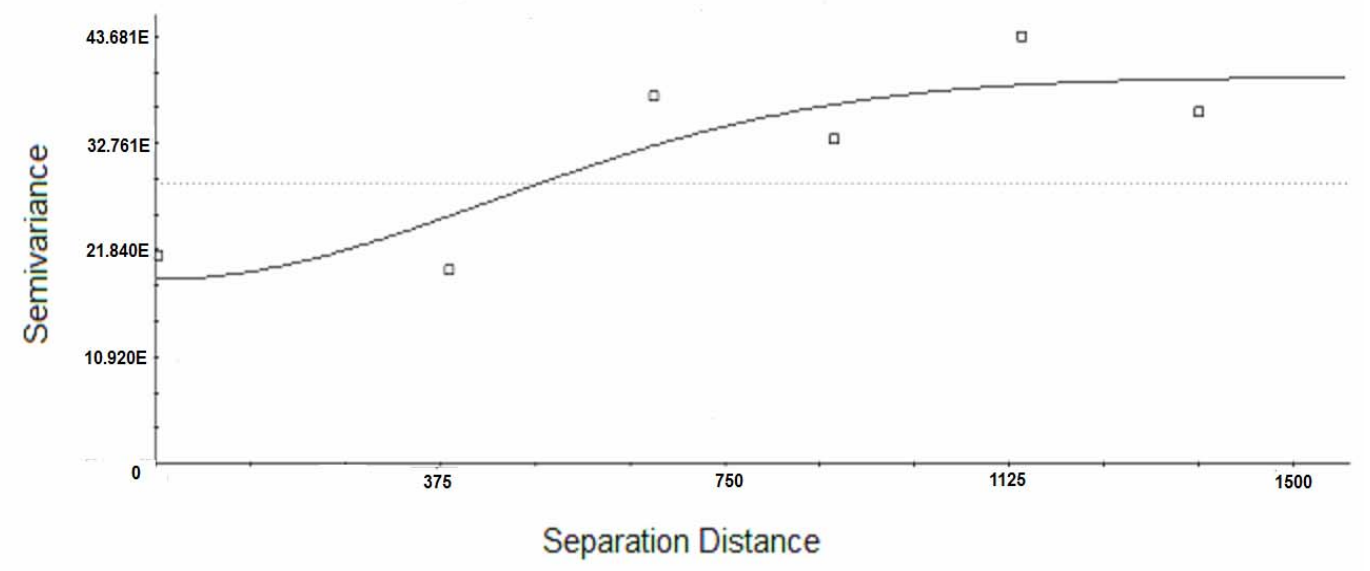

Figure 3. Isotropic semivariogram of mobile $\mathrm{Si}$, Gaussian model $(\mathrm{C} 0=\mathbf{1 8 8 6 0 0 . 0 0 0 0}$; $\left.\mathrm{CO}+\mathrm{C}=394900.0000 ; \mathrm{Ao}=631.00 ; \mathrm{R}^{2}=0.735 ; \mathrm{RSS}=1.101 \mathrm{E}+10\right)$

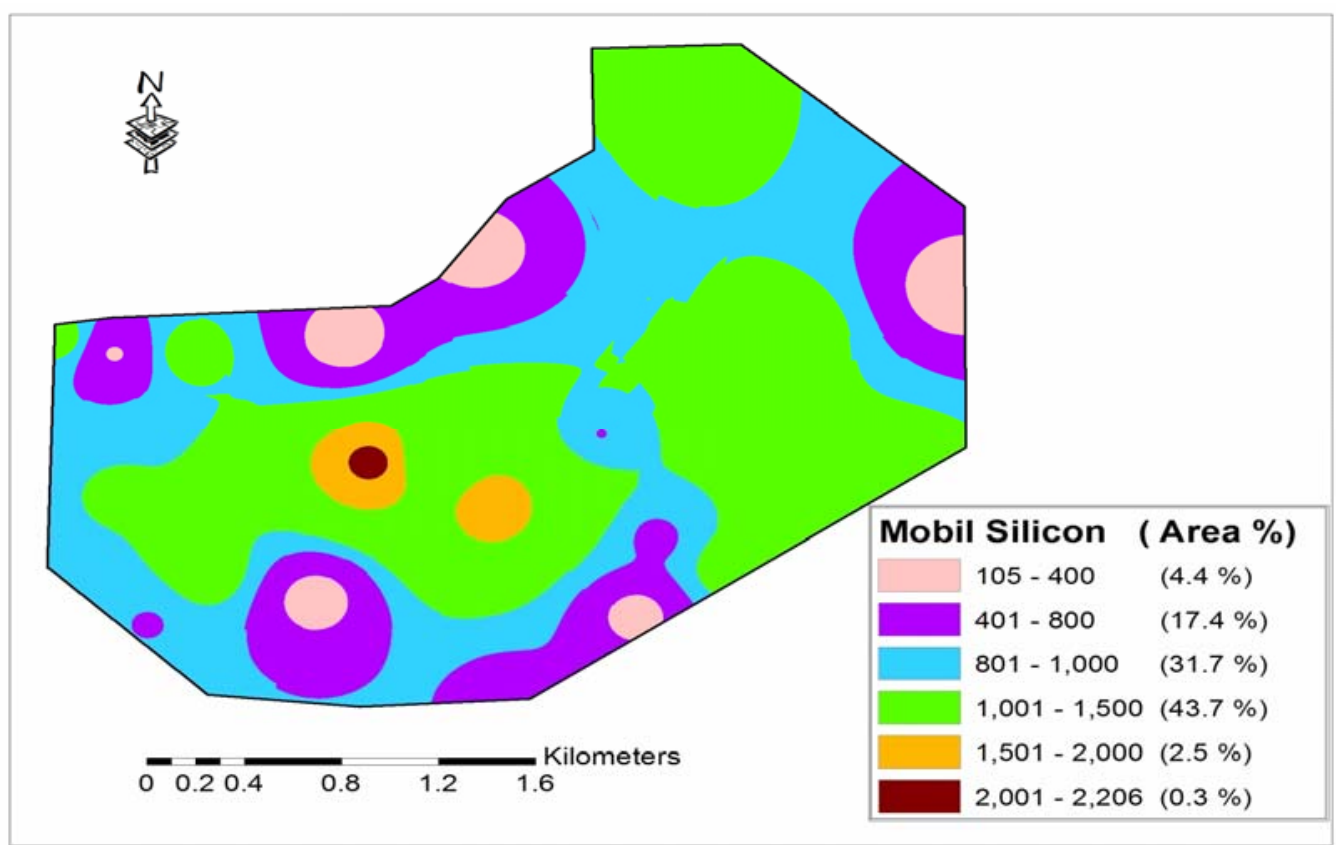

Map 4. Spatial distribution of mobile silicon $\left(\mathrm{mg} \mathrm{kg}^{-1}\right)$ in the top soil of the area

Table 4. Regression models describing the relationship between mobile and total or the other inorganic Si fractions

\begin{tabular}{ll}
\hline \multicolumn{1}{c}{ Regression equations } & $\mathbf{R}^{\mathbf{2}}$ \\
\hline $\mathrm{Y}=234.5+1.077 \mathrm{X}\left(\mathrm{Si}_{\text {ads }}\right)$ & 0.702 \\
\hline $\mathrm{Y}=422.2+1.120 \mathrm{X}\left(\mathrm{Si}_{\text {occ }}\right)$ & 0.517 \\
\hline $\mathrm{Y}=577.2+1.111 \mathrm{X}\left(\mathrm{Si}_{\text {om }}\right)$ & 0.376 \\
\hline $\mathrm{Y}=672.9+1.577 \mathrm{X}\left(\mathrm{Si}_{\text {am }}\right)$ & 0.273 \\
\hline $\mathrm{Y}=842.3+0.376 \mathrm{X}\left(\mathrm{Si}_{\text {min }}\right)$ & 0.095 \\
\hline $\mathrm{Y}=235.1+0.242 \mathrm{X}\left(\mathrm{Si}_{\text {total }}\right)$ & 0.697 \\
\hline $\mathrm{Y}=\mathrm{m}$
\end{tabular}


The lower mobile Si class was 105 to $400 \mathrm{mg} \mathrm{kg}^{-1}$ soil and covered about $4.4 \%$ of the area. The total percentage of $\mathrm{Si}$ in the mobile fraction indicates that some amounts of $\mathrm{Si}$ are potentially available for plants uptake in these soils. The amount of Si associated with the different phases follow the trend: mobile $>$ adsorbed $>$ occluded in sesquioxides $>$ bound to organic substances $>$ mineral (primary and secondary silicates) $>$ ammorphus. The mobile fraction contained most of $\mathrm{Si}$ in the non residual fractions.

The relationship between the mobile Si amounts and each fraction of $\mathrm{Si}$, were investigated by conducting a simple regression analysis. Also, the mobile amounts were regressed with the total amount of Si (Table 4). The availability of soil Si to plant during the growing season may be a function of the solubility and amounts of all or of certain fractions of the Si present in the soil especially adsorbed $\left(R^{2}=0.702\right)$ or occluded $\left(R^{2}=0.517\right)$ Si fractions.

As shown in Tables( 2) and (3), the amounts of Si in the mobile and adsorbed fractions are the higher than the other fractions. On the other hand, the amounts of amorphous $\mathrm{Si}$ are the lower in all soil samples. Silicon from amorphous silica and organically bound silicon make up the lowest proportion of extractable silicon in the soils analyzed in this study. However it comprises only up to $15.58 \%$ of total $\mathrm{Si}$.

The majority of silicon in the investigated soils is in mobile fraction. The method needs to be applied to more soils with different parent materials in order to obtain an overview about typical ranges in the proportions of the different $\mathrm{Si}$ fractions in soils. The nature of parent materials in these areas could also explain the low Si levels in these soils. As such, part of the studied areas where these soils were collected from, may potentially benefit from $\mathrm{Si}$ fertilization. Plant uptake studies may also be useful to justify whether it contributes to the low levels of Si in Banger Elsokkar Region.

\section{REFERENCES}

Anna D. S., Daniela B., Jörn H., Ludger Z. Mehdi and S. Karl (2010): Development of a method for sequential extraction of Si-pools from soils. World Congress of Soil Science, Soil Solution for a Changing World, 1-6 August 2010, Brisbane. Published on DVD, PP.31-34.
Buckley DeE. and R.E. Cranston, (1971): Atomic absorption analyses of 18 elements from a single decomposition of aluminosilicate. Chemical Geology, 7: 273-284.

DeMaster D.J. (1981): The supply and accumulation of silica in the marine environment. Geochimica et Cosmochimica Acta, 45: 1715-1732.

Epstein E. (1994): Silicon. Ann. Rev. Plant Physiol. Plant. Mol. Biol., 50: 641-664.

Holleman AF and N. Wiberg (2007): Lehrbuch der anorganischen chemie 102. Verlag de Gruyter, Berlin, pp.918.

Hammond K.E., D.E. Evans and M.J. Hodson (1995): Aluminium/silicon interactions in barley (Hordeum vulgare L.) seedlings. Plant Soil, 173:89-95.

Iwasaki K, P., Meier M., Fecht and W.J. Horst, (2002): Effects of silicon supply on apoplastic manganese concentrations in leaves and their relation to manganese tolerance in cowpea (Vigna unguiculata (L.) Walp). Plant Soil, 238:281-288.

Kovda V.A. (1973): The basis of learning about soils. Volume 2, Nauka, Moscow.

Liang Y.C., Q.R., Shen Z.G. Shen and T.S. Ma (1996): Effects of silicon on salinity tolerance of two barley cultivars. J. Plant Nutr. 19:173-183.

Marschner H. (1996): Mineral Nutrition of Higher Plants. Second Ed. Academic Press INC San Diego, CA 92101.

Matichenkov V.V. and D.V. Calvert (2002): Silicon as beneficial element for sugarcane. J. American Society of Sugarcane Technologists, Volume 22: 21-30.

Morsy M.A. (2008): Silicon in Agriculture conference. Wild Coast Sun, KwaZulu-Natal, South Africa, 26-31 October.

Page A.L., R.H., Miller D.R.(Keeney 1982): Methods of Soil Analysis. Second Ed. Am. Soc. Agron., Madison, Wisconsin, USA.

Sauer D. L, D.J, Saccone L, Conley Herrmann and M. Sommer (2006): Review of methodologies for extracting plant-available and amorphous Si from soils and aquatic sediments. Biogeochemistry, 80 (1): 89-108.

Savant N.K., G.H Korndorfer and L.E. Datnoff (1977): Silicon management and sustainable rice production. Advanc.Agron. 58:151-199.

Sommer M., D., Kaczorek Y. Kuzyakov and J. Breuer (2006): Silicon Pools and Fluxes in Soils and Landscapes - A Review. J. Plant Nutr. Soil Sci., 169:310-329. 


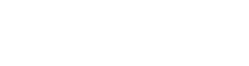

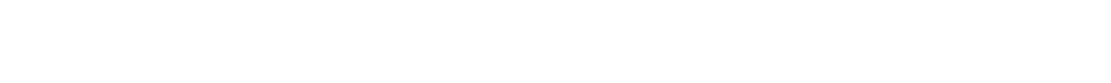

هدى أرجيعة، ماهر نسيم، هدى عبد الفتاح، ملجدة البو المجد

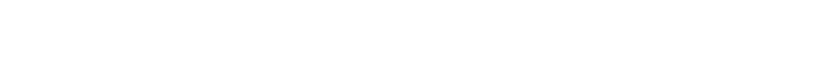

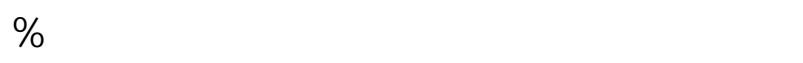
من المسلحة ويلي ذك الظلق الذي يتراوح فيه للسليكون

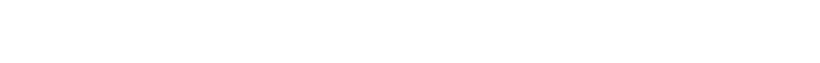

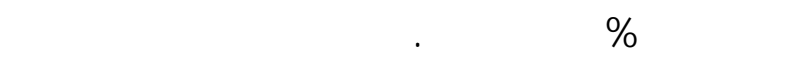
المتعاقب إلى أن مغظم اللسليكون كلن فـ الصورة المتحركة

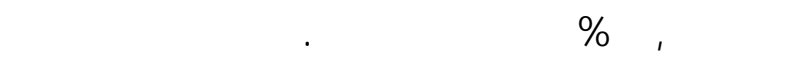

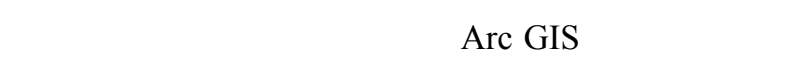

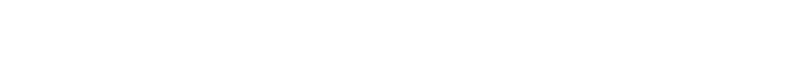

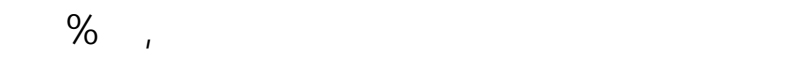

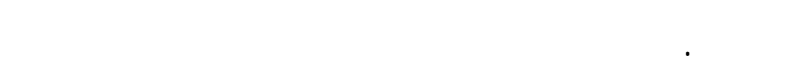

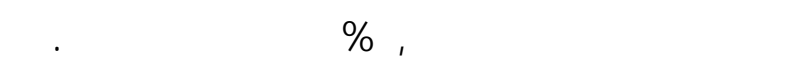

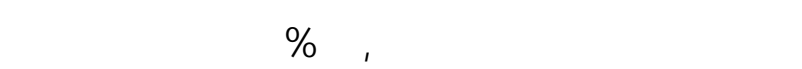
مرتبط بللسليكت الأولية والثانوية.
يوجد عددقليل من الدرلست والتي تتعلق بحالة السليكون في الأراضي المصرية. ومن هنا كانت هذه الدرلسة بهرف الديل

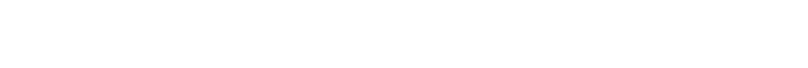
للسكر في مصر. وقد مق جمع 7r عينة تربة من ثلاث قرى

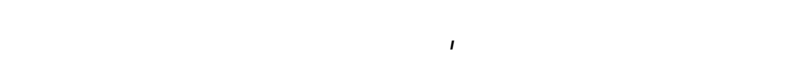
الكلى فيها وأيضا صور اللسليكون بلستخدلم الإتخلاص المتعاقب. وكثفت هذه الدرلسة أن محتوى للسليكون الكلى فلى

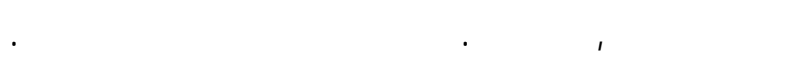
ولقد وجد أن أعلى التركيزت من للسليكون في الأراضي ذات القولم الغشن وأيضا كلن محتوى الطين والرهل وللسلت أكثر تأثيرا في المساهمة في محتوى اللسليكون الكل. - الم وبلستخدلم تقنية التصنيف بظلم برمجيت Arc GIS تقسيم المسلحة التي تحت الدرلسة إلى 7 ظلقلت تختلف في الفي 